\title{
USING GOOGLE CLASSROOM TOOLS IN TEACHING STUDENTS OF ECONOMIC SPECIALITIES
}

\author{
Oleksandr Stavytskyi \\ National Technical University of Ukraine "Igor Sikorsky Kyiv Polytechnic Institute”, \\ Kyiv, Ukraine \\ a_stavitsky@ukr.net \\ Marjan Urazgaliyeva \\ Aktobe University named after S. Baishev, Aktobe, Republic of Kazakhstan \\ urazgaliyevama@mail.ru
}

\begin{abstract}
The article deals with the issue of teaching students of economic specialities by means of cloud technologies. The author analyses the possibilities of applying Internet services and demonstrates the feasibility of their implementation in education. The primary aim of this research is to examine the influence of Google Classroom tools on the development of students' economic competence. During the pedagogical experiment, the criteria (cognitive, motivational and technological), indicators, and levels (high, sufficient, average and low) of the formation of students' economic competence through Google Classroom were determined. 65 students of the Faculty of Management and Marketing of the National Technical University of Ukraine "Igor Sikorsky Kyiv Polytechnic Institute" took part in the experiment. The results prove that Google Classroom tools allow increasing the level of cognitive activity and motivate students to study economic subjects. The paper demonstrates that the use of Internet resources has a positive effect on the development of technology skills and also favourably promotes the introduction of new methods into the educational process.
\end{abstract}

Keywords: Google Classroom; information and communication technologies; economic competence; cognitive criterion; interactive teaching methods; motivation.

\section{Introduction}

Nowadays the information and communication technologies develop quickly. New technologies appear and penetrate into all spheres of human life. In the educational process, students use more gadgets and services that's why new methods and techniques for teaching students should be developed. Due to the rapid growth of computer tools, many educational institutions try to apply social networks and various online services in the educational process. There is a need to develop a new methodology for teaching students of different specialities with the use of computer programs. It is necessary to create certain standards and criteria for the implementation of e-learning.

Schneckenberg (2014) emphasised that the increased interest in the field of cloud technologies stimulates a large amount of research. Various methods of presenting information using computer appear. Kondos (2018) stated that the role of the teachers in the classroom has changed in the digital age, where teachers are no longer the only source of knowledge. Picatoste et al. (2018) proved that nowadays the socalled fourth digital revolution is taking place, the impact of which will affect the current lifestyle of people and society. This development of technology should indicate the need for changes in higher education institutions in order to successfully integrate into an ever-changing world. Universities tend to play a major role in generating innovative solutions and in developing new programmes for learning. The introduction of training with the use of information and communication technologies in higher education institutions as an alternative curriculum will allow enrolling more students. The ability to use technology will make students more competitive in the labour market.

Researchers underline that 21st century Web 2.0 technologies, such as Edmodo, Google Docs, Zohowriter, Blogs, Wikis, and Facebook can be used in mixed or virtual classrooms, forums, or courses (Eid Hamoudeh et al., 2018). They play an important role in promoting mutual interaction, collaborative platforms for communication and learning among people. Some public cloud computing servers, such as Google, Google Drive, OneDrive, Dropbox, Mendeley documents can be used for training and exchanging data, files, and information. Google Talk and Skype can be involved to communicate remotely with a workgroup elsewhere (Dajun et al., 2014). Teaching models mediated through computers attract new ways of teaching and learning beyond spatial and temporal coordinates. E-learning, blended learning, and mobile learning offer a new universe of interactivity for learning purposes (Bartolomé-Pina et al., 2018).

Web 2.0 technologies help to conduct asynchronous workshops using online classroom resources (Cummings, 2016, p. 81). It is easy to use Google Apps (Google (+), Google Hangouts, Google Disc for learning. Cummings (2016) stated that interactive work with the online class using Web 2.0 technologies can 
help students to participate as much as possible in the learning process, as well as to establish flexible communication for performing various tasks.

Usage of Google Classroom tools has a lot of advantages. Researchers stated that "Google Classroom despite its simplicity and the absence of many features compared to Moodle is able to replace this robust system in many cases" (My \& Samkova, 2016) and proved that Google Classroom tools provide efficient homework submitting and checking. Students can use Google Classroom from any digital device with Internet access. Completed tasks are always in the Google Classroom, they can always be accessed and checked. The main advantage of Google Classroom is that all tasks are displayed in chronological order and it is indicated when they should be completed and handed over. Thus, the very possibility of forgetting the fulfilment of the task in the required period is excluded.

Scientists study the formation of economic competence and research its criteria and indicators. Antoniuk (2018) defined the following criteria for business simulations: design-didactical, technological and organisational. Sergeeva \& Nikitina (2016) determined the level of economic competences by three criteria: cognition, motivation, and activity.

The primary aim of this research is to examine the influence of Google Classroom tools into forming the economic competence of students. The focus of the paper will be on defining criteria, indicators, and levels of forming the economic competence by means of Google Classroom tools. The hypothesis of the study is that the effectiveness of students' professional training increases if the formation of economic competence is carried out with the use of Google Classroom tools.

\section{Methods}

In order to confirm the effectiveness of teaching with the use of information and communication technologies, a pedagogical experiment was conducted at the National Technical University of Ukraine "Igor Sikorsky Kyiv Polytechnic Institute" in the first semester of 2017/2018 academic year. Two groups of the third year of studying of the Faculty Management and Marketing were chosen for the experiment. The essence of the pedagogical experiment was as follows: one group was selected as a control (CG), and the other group was experimental (EG). The control group consisted of 35 students, and in the experimental group, there were 32 students.

To conduct the experiment, the course "Econometrics" using the electronic resources of the Google Classroom was developed. The course was designed for classwork (lectures and laboratory work) and for individual work at home. Students of experimental and control groups used books and handouts at the lessons. Students of the experimental group used Google Classroom service that included lecture materials in the form of presentations, video files on topics and text documents, as well as options for homework assignments, tests, questionnaires, and references. To discuss the issues, a forum was created with the ability to add comments. See Table 1 as a guide of Google Classroom tools for teaching students.

The course used a wide range of Google Classroom tools such as adding new members, co-teaching, flexible template management for creating individual tasks, centralised storage of resources and drawing up of individual tasks. The class is always accessible through the Google Class applications for the Android and iOS operating systems. It can be easily integrated into the information system of an educational institution with full protection of users' personal data. Through the administrator's service, it is possible to generate reports on the use of the class.

Table 1

Google Classroom tools for teaching students

\begin{tabular}{|l|l|}
\hline \multicolumn{1}{|c|}{ Tools } & \multicolumn{1}{c|}{ Description } \\
\hline Data sharing & Students can use the same data of the course simultaneously. \\
\hline Studying of materials & It is possible to study and discuss books, lectures and reports. \\
\hline Message & The tool helps to inform participants. \\
\hline Help & $\begin{array}{l}\text { System supports users. Students can ask for the help if they don't know how } \\
\text { to use some tools. }\end{array}$ \\
\hline Network disk & $\begin{array}{l}\text { A disk located on the server hosts all the necessary information for students } \\
\text { and teachers. }\end{array}$ \\
\hline Calendar & This is a tool for setting up assignments, deadlines, etc. \\
\hline Hypertext & The text contains links to other resources. \\
\hline
\end{tabular}

(to be continued) 


\section{Google Classroom tools for teaching students (continued)}

\begin{tabular}{|c|c|}
\hline Tools & Description \\
\hline Hyperlink & There is an interconnection among web pages. \\
\hline Poll (voting) & This is a tool for conducting quick surveys on specific topics. \\
\hline Group software & $\begin{array}{l}\text { A teacher can divide students into several groups for solving group tasks. The } \\
\text { program allows coordinating activity among a group of students. }\end{array}$ \\
\hline Web board & This is a resource for placing ads. \\
\hline Database & A data warehouse is available to a large group of users. \\
\hline Information security & $\begin{array}{l}\text { A list of rules is designed to protect information. Students receive information } \\
\text { on how to save the data. }\end{array}$ \\
\hline Content & $\begin{array}{l}\text { A teacher can easily add any resources to the Google Class (videos from } \\
\text { YouTube, Google forms, files from a virtual disk, pdf files, etc.). }\end{array}$ \\
\hline News & $\begin{array}{l}\text { Service shows the news of the course. A teacher can inform students about all } \\
\text { changes. }\end{array}$ \\
\hline Mailing list & $\begin{array}{l}\text { Teacher receives a list of email addresses that can be used to provide } \\
\text { information to a large number of participants. }\end{array}$ \\
\hline Feedback & Students can add their resources and comment activities. \\
\hline Visitor counter & This is a student activity accounting service. \\
\hline Forum, web conference & The tool for communication inside the class. \\
\hline E-book & All books can be stored in electronic format. \\
\hline $\begin{array}{l}\text { Comments, voice } \\
\text { comments }\end{array}$ & Ability to comment on the tasks and activities. \\
\hline Different applications & $\begin{array}{l}\text { A lot of applications integrate with Google Classroom (BookWidgets, Math } \\
\text { games, OpenEd.com, EDpuzzle, etc). It is possible to create different games } \\
\text { and fun activities (puzzle, crossword). }\end{array}$ \\
\hline
\end{tabular}

During the pedagogical experiment, the criteria, indicators, and levels of the formation of students' economic competence through Google Classroom were determined. Table 2 presents the criteria and indicators of formation of students' economic competence. In order to check the motivational criterion of the formation of economic competence, we used questionnaires (Magura \& Kurbatova, 2007), which were developed for analysing the motives of studying. Technological criterion presents informational and technological skills of students, their awareness in the application of new economic technologies. For determining the level of formation of the technological criterion, the methods of questioning and survey were used.

Table 2

The criteria and indicators of formation of students' economic competence with the use of Google Classroom

\begin{tabular}{|c|c|c|}
\hline Cognitive criterion & Technological criterion & \multicolumn{1}{|c|}{ Motivational criterion } \\
\hline $\begin{array}{l}- \text { knowledge of terminology; } \\
- \text { using appropriate methods of } \\
\text { information analysis; } \\
- \text { ability to solve economic } \\
\text { tasks. }\end{array}$ & $\begin{array}{c}\text { Google Class, Excel, Gretl, etc.; } \\
- \text { analysis and evaluation of } \\
\text { mathematical models. }\end{array}$ & $\begin{array}{l}\text { - interest in } \\
\text { Econometrics; } \\
- \text { understanding the importance } \\
\text { of applying theoretical knowledge } \\
\text { in practice; } \\
- \text { interest in individual work. }\end{array}$ \\
\hline
\end{tabular}

The following methods were used during the experiment: surveys, tests, individual and group surveys, teacher monitoring, quantitative and qualitative data processing methods. Experimental work was carried out in several stages. 
1) In the first stage, an ascertaining experiment was conducted, the main purpose of which was to study the level of students' economic competence. In a questionnaire, 65 students of speciality "Economics" of Igor Sikorsky Kyiv Polytechnic Institute were surveyed at the beginning of the semester. The groups participated in the pedagogical experiment passed an initial assessment.

2) At the second stage, the experimental group was trained using materials in the form of presentations, videos, and textual documents in the Google Classroom. During lectures and practical classes, students studied the topics of the "Econometrics" course using Google Classroom resources. They studied video files and presentations, as well as electronic texts, and then solved economic tasks using Microsoft Excel. Students did their homework using the Google Classroom resources studying relevant topics and solving thematic problems, they also wrote essays and prepared one joint project. Teaching students of the control group was carried out without systematic use of information and communication technologies.

3) At the final stage, the analysis of the results of experimental research with the help of mathematical methods was carried out. Two modular tests and one examination test were conducted. The evaluation was displayed in the personal students' accounts.

\section{Results}

The data obtained in the analysis of quantitative and qualitative results of the experiment on the implementation of information and communication technologies in the educational process of students of economic specialities indicate the effectiveness of the teaching methods. A comparative analysis of the results revealed the positive dynamics of the levels of forming economic competence of the experimental group, while there were no significant changes in the control group of students. Students of the experimental group demonstrated high and sufficient levels of cognitive, motivational and technological criteria. $53.8 \%$ of EG students showed a high level of cognitive criterion formation, $27.4 \%$ showed sufficient level, $14.5 \%-$ average level, $4.3 \%$ - low level. The levels of the cognitive criterion formation in CG were as follows: high - in $22.6 \%$, sufficient - in $23.2 \%$, average - in $38.4 \%$, low - in $15.8 \%$. The results are shown in Table 3 .

Levels of formation of economic competence after the formative experiment, $\%$

Table 3

\begin{tabular}{|l|c|c|c|c|c|c|}
\hline \multirow{2}{*}{ Levels } & \multicolumn{6}{c|}{ Criteria } \\
\cline { 2 - 7 } & \multicolumn{2}{|c|}{ Cognitive } & \multicolumn{2}{c|}{ Technological } & \multicolumn{2}{c|}{ Motivational } \\
\cline { 2 - 7 } & CG & EG & CG & EG & CG & EG \\
\hline High & 22,6 & 53,8 & 24,5 & 48,3 & 20,4 & 36,7 \\
\hline Sufficient & 23,2 & 27,4 & 36,6 & 31,4 & 25,7 & 42,4 \\
\hline Average & 38,4 & 14,5 & 22,3 & 16,7 & 42,4 & 17,3 \\
\hline Low & 15,8 & 4,3 & 16,6 & 3,6 & 11,5 & 3,6 \\
\hline
\end{tabular}

The effectiveness of the experiment was confirmed by the obtained efficiency coefficients in terms of the average number of correctly performed tasks $\left(K_{b}=1,24\right)$ and in terms of the standard deviation ( $K_{p}=0,62$ ). The obtained results give us the opportunity to argue that the use of Google Classroom service in teaching students influences positively the formation of economic competence.

As hypothesised, our experiment proves that the effectiveness of students' professional training increases if the formation of economic competence is carried out with the use of Google Classroom tools.

\section{Discussion}

Results of the formative experiment showed positive changes in the levels of formation economic competence of the experimental group in comparison with the control group. From the results, it is clear that usage of Google Classroom tools increases the knowledge of terminology and ability to solve economic tasks. Overall these findings are in accordance with findings reported by Sergeeva et al. (2016). The Google Classroom application is integrated with problem-based learning, that helps in solving different tasks. The Google class application contains material related to learning topics and practical issues (Pritasari \& Jumadi, 2018). 
Students of the experimental group are more motivated to study Econometrics; they understand the importance of applying theoretical knowledge in practice. A similar conclusion was reached by Rana et al. (2018) who proved that the use of Google classrooms is easy and useful, and students are highly motivated toward the incorporation of such pedagogical tools in their learning process.

The obtained results prove that students also increase their technology skills. They are able to use such programs as Google Class, Excel, Gretl more effectively. A similar pattern of results was obtained in the previous studies (Abazi-Bexheti et al., 2018). Researchers stated that Google services have their own strengths and weaknesses, but their use stimulates students to improve their computer skills. Google Classroom service is seen as a technological alternative to traditional silent discussions (Roberts, 2013).

Abazi-Bexheti et al. (2018) stated that "E-learning is equally seen as the cause and result of important changes in the nature of the concept of education, as well as changes in how it should be successfully delivered". The pedagogical experiment conducted using the full functionality of the Google Classroom software service proves that the chosen service is an excellent tool for increasing the effectiveness of student learning as it ensures timely execution of work, quick access to the course, and information integrity. The service allows reducing the time for verification, correction, and preparation of new tasks. It also allows the students to learn at their own comfort and requirement.

Usage of Google Classroom tools is an effective way of teaching students. The service increases the level of professional competence of future economists and it influences the students' motivation. Students are more interested to study that is quite important for achieving professional goals. The results are due precisely to the use of experimental methods.

The main limitation of the research is the lack of data about influence on self-studying. The analysis does not enable us to determine positive or negative factors of studying individually. It remains unclear whether using Google Classroom tools give benefits for studying material alone at home. Further study of the issue is still required.

In future research, we recommend studying the usage of Google Classroom services for other disciplines. It is necessary to research the influence of the tools for the development of competences in other fields of study. We also consider it necessary to introduce other multimedia programs into the educational process.

\section{Conclusions}

The findings of our research are quite convincing, and thus the following conclusions can be drawn: using Google Classroom tools influences positively into the formation of the economic competence of university students. The service activates the cognitive activity of students at lectures and individual studying, ensures the availability of materials at any time. It stimulates interest in learning and creates the appropriate conditions for the formation and development of technological skills.

Further, promising use of the Google Classroom software service will allow creating elements of distance learning that can ensure a continuous and sustainable learning process when influenced by various negative factors, such as quarantine, natural anomalies, and long-term forced absence of students in an institute.

\section{References:}

Abazi-Bexheti, L., Kadriu, A., Apostolova-Trpkovska, M., Jajaga, E., \& Abazi-Alili, H. (2018). LMS solution: evidence of Google Classroom usage in higher education. Business Systems Research, 9 (1), 31-43. https://doi.org/10.2478/bsrj-2018-0003

Antoniuk, D. S. (2018). Business simulations for the formation of economic competence of technical specialties students: criteria and indicators of selection. Information Technologies and Learning Tools, 64 (2), 73-87

Bartolomé-Pina, A., García-Ruiz, R., \& Aguaded, I. (2018). Blended learning: overview and expectations. Revista Iberoamericana de Educación a Distancia, 21 (1), 33-56. https://doi.org/10.5944/ried.21.1.18842

Catalano, A. (2015). The effect of a situated learning environment in a distance education information literacy course. Journal of Academic Librarianship, 41 (5), 653-659. https://doi.org/10.1016/j.acalib.2015.06.008

Cummings, L. (2016). Flipping the online classroom with Web 2.0: the asynchronous workshop. Business and Professional Communication Quarterly, 79 (1), 81-101. https://doi.org/10.1177/2329490615602250

Dajun, X., Cees, B., \& Guobiao, C. (2014). Framework of concurrent design facility for aerospace engineering education based on cloud computing. Moving Integrated Product Development to Service Clouds in the Global Economy, 477-483. https://doi.org/ 10.3233/978-1-61499-440-4-477

Eid Hamoudeh, A., Samsiah, A., \& Bashir, I. (2018). Technology-supported online writing: an overview of six major web 2.0 tools for collaborative-online writing. Arab World English Journal, 9 (1), 433-446. https://doi.org/10.24093/awej/vol9no1.30

Karpova, O. (2017). The implementation of the multimedia approach to teaching business English. Advanced Education, 8, 10-15. https://doi.org/10.20535/2410-8286.98433

Kondos, S. (2018). The effect of the use of technology on the nature of teacher's profession. Arab World English Journal, 9 (1), $220-$ 232. https://doi.org/10.24093/awej/vol9no1.16 
Magura, M. \& Kurbatova, M. (2007). Sekreti motivacii. Ili motivacija bez sekretov [Secrets of motivation. Or motivation without secrets]. Moscow, Russia: Upravlenie personalom.

My, K., \& Samková, L. (2016). Analysis of the possibilities of using Google Classroom as Moodle replacement. Proceedings of the Central \& Eastern European LUMEN International Conference (pp. 322-331). http://dx.doi.org/10.15405/epsbs.2017.07.03.40

Picatoste, J., Perez-Ortiz, L., \& Ruesga-Benito, S.M. (2018). A new educational pattern in response to new technologies and sustainable development. Enlightening ICT skills for youth employability in the European Union. Telematics and Informatics, 35 (4), 1031-1038. https://doi.org/10.1016/j.tele.2017.09.014

Pritasari, C. A., \& Jumadi, J. (2018). Development of science learning tool based on problem based learning with Google Classroom to improve argumentation skill. Biosaintifika, 10 (2), 348-355. https://doi.org/10.15294/biosaintifika.v10i2.14320

Rambe, P. (2017). Spaces for interactive engagement or technology for differential academic participation? Google Groups for collaborative learning at a South African University. Journal of Computing in Higher Education, 29 (2), $353-387$. https://doi.org/10.1007/s12528-017-9141-5

Rana, A., Al-Maroof, S. \& Al-Emran, M. (2018). Students' acceptance of Google Classroom: An exploratory study using PLS-SEM approach, iJET, 13 (6), 112-123. https://doi.org/10.3991/ijet.v13i06.8275

Roberts, S. (2013). The "chalk talk" 2.0: using Google Docs to improve the silent discussion in social studies. The Social Studies, 104, 130-136. https://doi.org/10.1080/00377996.2012.703972

Schneckenberg, D. (2014). Easy, collaborative and engaging - the use of cloud computing in the design of management classrooms. Educational Research, 56, 412-435. https://doi.org/10.1080/00131881.2014.965569

Sergeeva, M.G., \& Nikitina, E.E. (2016). Criteria indicators of formation of economic competence of system of the general education. Proceedings of the SHS Web of Conferences, 9 (pp. 1-3). https://doi.org/10.1051/shsconf/2016

Seung, H., Sergueeva, K., Catangui, M., \& Kandaurova, M. (2017). Assessing Google Cardboard virtual reality as a content delivery system in business classrooms. Journal of Education for Business, 92 (4), 153-160. https://doi.org/10.1080/08832 323.2017.1308308

Solihati, N., \& Mulyono, H. (2017). A hybrid classroom instruction in second language teacher education (SLTE): a critical reflection of teacher educators, iJET, 12 (5), 169-180. https://doi.org/10.3991/ijet.v12i05.6989

Received: September 03, 2018

Accepted: December 04, 2018 